\title{
Białe Orły komiksu. Wokół polskiej specyfiki narracji superbohaterskich
}

Tomasz Żaglewski 


\section{Białe Orły komiksu. Wokół polskiej specyfiki narracji superbohaterskich}

Tomasz Żaglewski

\section{Opowieść superbohaterska jako amerykański monomit}

Ogromne znaczenie, jakie dla tradycji komiksu amerykańskiego mają opowieści o superbohaterach, najłatwiej uzmysłowić sobie dzięki temu, że - jak twierdzi chociażby Dave Gibbons, autor ilustracji do kultowych Strazników Alana Moore'a - „superbohaterowie są gatunkiem, który zawładnął całym medium [komiksowym - przyp.T.Ż.]"1. Zrozumienie głębokiej fascynacji, jaką amerykańscy czytelnicy darzą swoich idoli „w trykotach” wymaga w tym przypadku gruntownej rekonstrukcji fundamentalnych kulturowych mechanizmów, w jakie wyposażone zostały już pierwsze historycznie przykłady superheroicznych narracji. Zdaniem Jeffreya K. Johnsona - autora monografii Super-History. Comic Book Superheroes and American Society, 1938 to the Present - sam moment „wynalezienia" nowoczesnej idei superbohatera (symbolizowany oczywiście przez pojawienie się Supermana na kartach

1 L. Burke The Comic Book Film Adaptation. Exploring Hollywood's Leading Genre, University Press of Mississippi, Jackson 2015, s. 8.

\author{
Tomasz Żaglewski \\ - dr, adiunkt w Insty- \\ tucie Kulturoznaw- \\ stwa UAM, sekretarz \\ redakcji pisma "Studia \\ Kulturoznawcze". \\ Interesuje się historią \\ i teorią kultury popu- \\ larnej - w szczegól- \\ ności komiksu - oraz \\ komparatystyką \\ medialną. Ostatnio \\ opublikował: Kinowe \\ uniwersum super- \\ bohaterów. Analiza \\ współczesnego filmu \\ komiksowego (2017). \\ Kontakt: zaglewski. \\ tomasz@gmail.com
}


magazynu „Action Comics” nr 1 z 1938 roku) osadzony był bowiem głęboko w ówczesnych realiach społeczno-politycznych, zdefiniowanych przez wcześniejszy o zaledwie sześć lat program New Dealu autorstwa prezydenta USA - Franklina Delano Roosevelta.

Odziany w kostium mieniący się barwami amerykańskiej flagi twór pary emigrantów - Joe Shustera i Jerry'ego Siegela - szybko stał się ogólnokrajowym fenomenem na rynku opowieści komiksowych, odkrywających wówczas dopiero od niedawna potencjał sensacyjnych i awanturniczych tematów. Superman, jak słusznie zauważa Jeffrey K. Johnson, nie był jednak kolejnym, "płytkim" przykładem prostego, obrazkowego eskapizmu, lecz stał się raczej fantastycznym ucieleśnieniem socjo-gospodarczej polityki New Dealu wraz z jej naczelnym projektantem, czyli Franklinem Rooseveltem. Człowiek ze Stali w trakcie pierwszych lat swych obrazkowych przygód był bowiem najbardziej oczywistym (w ramach narodowej popkultury) przykładem zawartej w ramach Nowego Ładu filozofii, że „trzeba działać”, tzn. wziąć we własne ręce los swej najbliższej społeczności, a w konsekwencji także miasta i państwa. Znaczące, że podczas pierwszych lat swojego działania Superman „walczył z chorobami społecznymi i bardziej przyziemnym typem kryminalisty, który miał przywoływać w czytelniku wrażenie czegoś znajomego"2 ${ }^{\text {. Podstawo- }}$ wym zadaniem herosa było tu zatem przede wszystkim radzenie sobie ze skutkami biedy oraz pospolitego bandytyzmu, a nie odpieranie nierealnych zagrożeń ze strony przerysowanych superzłoczyńców czy istot z kosmosu. Jak podsumowuje za Grantem Morrisonem Jeffrey K. Johnson: „Superman [...] był bohaterem ludu. Oryginalny Superman był śmiałym humanistą, który odpowiadał na koszmary ery Wielkiego Kryzysu symbolizowane tu przede wszystkim przez zdehumanizowany postęp naukowy oraz bezduszny industrializm"3.

Przedstawiona powyżej natura superbohatera stanowi najważniejszy element klasycznej struktury superbohaterskiej narracji komiksowej, która - z jedynie nieznacznymi aktualizacjami - przetrwała w tym swoistym gatunku do dnia dzisiejszego. Owa struktura - nazwana przez Roberta Jewetta i Johna Sheltona Lawrence'a amerykańskim monomitem (w nawiązaniu do kategorii Jospeha Campbella) - powinna się składać z następujących etapów prezentowanej opowieści:

2 J.K. Johnson Super-History. Comic Book Superheroes and American Society, 1938 to the Present, McFarland \& Company, Jefferson 2012, s. 12.

3 Tamże, s. 13. 
1. Wspólnota jest zagrożona,

2. Pojawia się bezinteresowny bohater,

3. Bohater przezwycięża pokusy,

4. Bohater osiąga zwycięstwo (poprzez swoje supermoce),

5. Bohater przywraca harmonię w społeczeństwie,

6. Bohater powraca do swojego odosobnienia ${ }^{4}$.

Powyższa wariacja na temat Campbellowskiego monomitu - opisującego tzw. podróż bohatera, charakterystyczną dla wielu kulturowych narracji religijno-heroicznych - nosi jednak w sobie wyraźne znamię ideologicznego dualizmu, kryjącego się za figurą amerykańskiego superbohatera. Zdaniem Jasona Dittmera, autora publikacji Captain America and the Nationalist Superhero. Metaphors, Narratives and Geopolitics, zaproponowany przez Jewetta i Lawrence'a wariant monomitu wyraźnie podkreśla obecną w ramach gatunku superbohaterskiego już od czasów oryginalnego Supermana liberalno-konserwatywną hybrydę. „Sugerujemy” - przywołuje słowa Jewetta i Lawrence'a Dittmera - „że w tej nowej odmianie mitu, który wykrystalizował swoje konwencje i fabuły w dekadzie lat 30., w postaci protagonisty objawia się demokratyczne oblicze Everymana, skrywające jednak w sobie elementy pop-faszyzmu poprzez fakt, że jest to jednostka niewybrana przez naród i przekraczająca normy prawa postać, która wykorzystuje swe nadludzkie moce, aby okiełznać wrogów"'. Kluczowy okazuje się tu zatem ostatni, odmienny od Campbellowskiego etap monomitu - (super)bohater nie integruje się bowiem w finale swoich zmagań ze społecznością, której bronił, lecz powraca do swej pozycji ponad zbiorowością, ponownie ewokując na myśl „ojcowską" figurę prezydenta Roosevelta, dobroduszną i opiekuńczą, lecz jednocześnie wymagającą i oddaloną od pojedynczego adresata New Dealu. Narodzona w epoce post-kryzysowej mitologia amerykańskich superbohaterów wyróżnia się zatem "brakiem ostatecznej integracji oraz chęcią wyzwolenia się ze społecznych reguł, które sama narzuca, łącząc się tym samym z silnym poczuciem amerykańskiej wyjątkowości w świecie"6. Amerykański monomit jako fundament superheroicznego eposu okazuje się w swej bazowej strukturze niczym innym, jak właśnie przejawem indywidualistycznego przekonania o ekonomicznej i kulturowej hegemonii USA, o którym zaświadczyć miałyby

\footnotetext{
4 P. Coogan Superhero. The Secret Origin of a Genre, MonkeyBrain Books, Austin 2006, s. 123.

5 J. Dittmer Captain America and the Nationalist Superhero. Metaphors, Narratives and Geopolitics, Temple University Press, Philadelphia 2013, s. 11.

6 Tamże.
} 
finansowe wpływy oraz szeroki zakres konsumenckich praktyk skupionych wokół globalnie rozpowszechnianych marek superbohaterskich.

Zatrzymanie się na powyższym wniosku byłoby jednak przejawem niezdrowego i nieuzasadnionego determinizmu kulturowego, zmierzającego do przyjęcia najbardziej pesymistycznych tez z czasów Szkoły Frankfurckiej na temat holistycznego wyzysku czytelników przez - komiksowy w tym przypadku - przemysł kulturowy. Właściwa i pożądana tu perspektywa kulturoznawcza domaga się bardziej refleksyjnego namysłu nad działaniem amerykańskiego monomitu - tym bardziej że społecznie ważni superbohaterowie występują także w pozaamerykańskich kontekstach lokalnych, choć oczywiście bez równie spektakularnych wyników finansowych. Przechodząc do próby wstępnego zdefiniowania owych "swojskich" herosów, należałoby przywołać Marca DiPaolo, którego zdaniem niemal każdy przykład superbohaterskiej opowieści można zaklasyfikować, pod kątem zawartych w niej dyskursów politycznych, do jednej z podstawowych kategorii dla tego typu fabuł: opowieści proestablishmentowej, antyestablishmentowej i opowieści kolonialnej. Zgodnie z intencjami autora: „W ramach pierwszej kategorii [...] superbohater walczy, aby zachować istniejące status quo oraz obronić rząd i populację przed atakiem z zewnątrz [...]. W ramach drugiej kategorii [...] superbohater znajduje się w opozycji wobec złego rządu, korporacji czy arystokratycznego złoczyńcy [...]. W ramach trzeciej kategorii superbohater podróżuje w kierunku dalekiej, niecywilizowanej [w domyśle: nie-amerykańskiej - przyp.T.Ż.] krainy, aby ją sobie podporządkować"7 Reinterpretując nieco zaproponowaną przez badacza typologię, można za jej pomocą opisać dostępne przykłady poza-amerykańskich narracji, sytuujących się wobec swych odpowiedników z wydawnictw DC lub Marvel w sposób afirmatywny (podejście establishmentowe), subwersywny (podejście antyestablishmentowe) lub też najbardziej uległy (kolonialny).

\section{Okres wielkiego post(u)}

Zgodnie z klasyfikacją zaproponowaną przez Nata Gertlera, ewolucję amerykańskiego komiksu superbohaterskiego można zrekonstruować za pomocą trzech etapów - lub też faz - charakterystycznych dla rozwoju tego typu fabuł: Faza 1 - Bohaterowie koncentrują się na walce ze złem; Faza 2 -

7 M. DiPaolo War, Politics and Superheroes. Ethics and Propaganda in Comics and Film, McFarland \& Company, Jefferson 2011, s. 12.

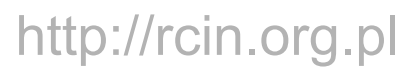


Bohaterowie koncentrują się na odkrywaniu powodów swojej walki ze złem; Faza 3 - Bohaterowie koncentrują się na rozpatrywaniu skutków swojej walki ze złem ${ }^{8}$. Klasyfikacja Gertlera dość ściśle pokrywa się z bardziej potocznym rozróżnieniem, obowiązującym w amerykańskim piśmiennictwie komiksoznawczym, na tzw. Złotą, Srebrną i Brązową Erę komiksu, odpowiednio datowanymi na lata 1938-1945, 1956-1970 oraz 1970-1985. Historię narracyjnej specyfiki amerykańskich opowieści superheroicznych da się opisać zatem poprzez schemat stopniowego narastania mechanizmów subwersywnych w ramach tego gatunku, prowadzących do - jak było chociażby w Powrocie Mrocznego Rycerza Franka Millera z 1986 roku - daleko idącego przewartościowania etosu superbohatera i zrównania go z rolą zanurzonego w polityczne dyskursy fanatyka.

Próbując przełożyć powyższy model diachroniczny na specyfikę polskich superbohaterów, szybko da się zauważyć, że ewolucja rodzimych herosów dokonywała się w sposób niemalże dokładnie odwrotny do amerykańskiego. Zanim bowiem polski czytelnik doczekał się „swojskich” odpowiedników klasycznych herosów rodem z amerykańskiego monomitu, polski rynek komiksowy - w znacznej mierze z racji uwarunkowań politycznych - podchodził do "trykociarzy" z daleko idącą ostrożnością, a wręcz niechęcią. Chcąc oddać sprawiedliwość historii polskiego komiksu, należy odnotować, że z pierwszymi próbami nawiązania pewnej formy kontaktu z „kapitalistycznymi” herosami doszło już w 1966 roku za sprawą serii Cień wydawanej na łamach „Słowa Ludu”. Komiks ten był dość dalekim nawiązaniem do oryginalnej pulpowej serii w ramach protosuperbohaterskiej literatury autorstwa Waltera B. Gibsona. W przeciwieństwie jednak do swojego odpowiednika zza oceanu, który był protoplastą późniejszych wyalienowanych i tajemniczych mścicieli, polskim „Cieniem” był Jan Derenda - żołnierz wojska polskiego, który po klęsce wrześniowej w 1939 roku powraca do rodzinnej miejscowości pod Kielcami, aby podjąć tam partyzancką walkę z niemieckim okupantem. Jak łatwo zauważyć, „swojski” Cień pretekstowo jedynie może być uznany za narrację superbohaterską w duchu amerykańskiego monomitu. Poza oczywistym brakiem elementów fantastycznych, brakuje tu również owego charakterystycznego elementu społecznego wyobcowania, cechującego oryginalnych komiksowych herosów. „Superbohater” Derenda realizuje swój lokalny, „nadludzki" mit przede wszystkim poprzez służbę ojczyźnie wraz z wiernym sobie

8 R. Duncan, M.J. Smith The Power of Comics. History, Form \& Culture, Continuum, New York 2009, S. 232. 
oddziałem, a nie dzięki przypisanemu mu „ponad-społecznemu” statutowi samotnego mściciela.

Tego rodzaju konstrukt charakterologiczny nie był zresztą możliwy do zaproponowania w polskim komiksie w okresie PRL-u, dla którego amerykańscy superbohaterowie - głównie z racji manifestowanego przez siebie wszem i wobec kultu indywidualizmu - stanowili idealną metaforę zagrożeń ze strony amerykańskiej kultury. Jak pisał za ówczesną prasą Adam Rusek: „tak konstruuje się ideał amerykańskiego nadczłowieka czy raczej - podczłowieka, coś w rodzaju strzelającej i gadającej małpy [...]. Superman obdarzony jest nie tylko nadludzką siłą, nadprzyrodzoną zdolnością pokonywania czasu i przestrzeni - pisano - [...], ale i wszystkimi przymiotami ducha, jakie odpowiadają naszym wyobrażeniom o faszyzmie. Jest to po prostu personifikacja amerykańskiej wersji faszyzmu. [...] jeżeli odznacza się nieuchwytnością i faktycznie jest postawiony w roli jakiegoś zmaterializowanego 'bóstwa', to poprzez to samo zaszczepia w jaźni młodzieńczej strach, histerię, poczucie obawy, że oprócz 'dobrego supermana' może istnieć 'zły superman', który zabija spokojnych ludzi i niszczy ich dobytek”' . PRL-owska pogarda dla wszelkiej maści „Supermanów” - zakorzeniona oczywiście głęboko w programie władzy komunistycznej, gloryfikującej oficjalnie kult ludu ponad kult jednostki - zaskakująco pokrywała się w swej krytyce z wcześniejszymi o niemal dekadę tezami amerykańskiego psychologa, dr Fredrica Werthama, który w swojej głośnej książce The Seduction of the Innocent. The Influence of Comic Book's on Today's Youth także starał się wykazać niszczycielskie działanie opowieści o superbohaterach, udowadniając m.in., że przemoc, sadyzm i okrucieństwo to cechy główne „filozofii supermana” (Superman był tu opisywany jako „tajny agent SS”), zaś młodzi czytelnicy komiksów nie szanują swoich ciężko pracujących rodziców, gdyż są wychowywani według nadludzkich - chciałoby się dodać, nierobotniczych - standardów komiksowych herosów.

PRL-owska władza nie mogła jednak całkowicie zignorować rosnącej fascynacji młodych czytelników przemycanymi - głównie zza niemieckiej granicy - przedrukami amerykańskich „Supermanów”. Nie mogąc pozwolić sobie jednak na oficjalne zaanektowanie „nieprawomyślnego” amerykańskiego monomitu, Polska Ludowa wykreowała - podobnie jak w przypadku Cienia Derendy - własną wersję superheroicznego idola, którego

9 A. Rusek Cykliczne historyjki obrazkowe w Polsce w latach 1945-1955, w: Ludzie i książki. Studia historyczne, red. J. Kostecki, Biblioteka Narodowa, Warszawa 2006, s. 331. 
superatrybuty zbudowane były jednak przede wszystkim na realizacji politycznego programu społecznej „normalizacji”. W 1967 roku polska kultura popularna wzbogaciła się o postać kapitana Jana Żbika - fikcyjnego funkcjonariusza Milicji Obywatelskiej, który stanowić miał „lokalną” odpowiedź na zachodnich herosów. Gigantyczna popularność postaci stworzonej przez Władysława Krupkę i rysowanej przez Grzegorza Rosińskiego, która trwała aż do roku 1982, pozwala mówić tu o jednym z pierwszych w Polsce zabiegów zmierzających do zaproponowania polskiego wariantu monomitu, aczkolwiek bardziej w wariancie afirmatywnym - a zatem wciąż zasadniczo podległym wzorcowi amerykańskiemu, niż całkowicie od niego niezależnym.

Już zresztą ówcześni komentatorzy fenomenu Żbika zdawali się - mniej lub bardziej świadomie - sugerować zasadniczą bliskość dzielnego milicjanta względem nadludzi z Zachodu, niezależnie od braku widowiskowych supermocy kapitana: „Czy naprawdę korzystanie z niektórych wzorów zachodnich jest aż taką zbrodnią?" - pytał retorycznie Zbigniew Bryczkowski - „Jeśli [komiksy - przyp. T.Ż.] służą rozbudzaniu zbrodniczych instynktów czy przesądów rasowych, jak to się niestety często zdarza w krajach zachodnich, to słusznie się spotykają z naszą krytyką. Ale korzystając z atrakcyjnej formy, można za pośrednictwem komiksów [...] wykształcać w społeczeństwie (zwłaszcza w najmłodszej jego części) szacunek dla obowiązujących praw, pobudzać sympatię dla przedstawicieli ładu i porządku, wyrabiać przekonanie, że przestępstwo nie popłaca. I takie jest właśnie założenie polskich komiksów”"10. Zatem mimo swej manifestowanej „ludowości”, przynajmniej jak na warunki PRL-u, Żbik pozostawał w swym narracyjnym źródle dalekim echem amerykańskich supermanów, „wzbogaconym” jedynie o politycznie poprawną wykładnię współpracy obywateli z milicją, sięgającą wręcz praktyk donosicielstwa. Doskonale podsumowuje ten aspekt w swojej monografii poświęconej postaci Żbika Mateusz Szlachtycz, który stwierdza: „To prowokacyjne porównanie Żbika do Supermana nie było kompletnie postrzelone. Bo jeśli omnipotencję organów MO, zwłaszcza błyskawiczne przeloty Żbika milicyjnymi śmigłowcami, korzystanie z maszyn analitycznych (takich prawie komputerów), noktowizorów etc. Potraktować jako substytut supermocy, a poliestrowe garnitury uznać za odpowiednik trykotu, to można supermilicjanta przyrównać do słynnego superbohatera. Jednak spośród słynnych komiksowych herosów bliżej mu do Batmana. [...]. Natomiast w młodych

10 M. Szlachtycz Kapitan Żbik. Portret pamięciowy, The Facto, Warszawa 2017, S. 129.

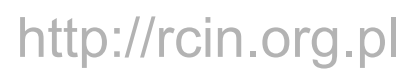


współpracownikach Żbika, zwłaszcza harcerzach, można dostrzec zmultiplikowanych Robinów"11.

W momencie swojego największego triumfu na polskim rynku komiksowym, Żbik pozostawał jednak zaskakująco mało „zlokalizowanym”, tzn. opartym na „swojskim” spojrzeniu, fenomenem, powielającym najczęściej dominujące na Zachodzie tropy fabularne. Pierwszym głęboko polskim, tzn. radykalnie "lokalnym” - zarówno tematycznie, jak i formalnie - superbohaterem okazała się tymczasem postać nie z kart komiksu, ale kinowych ekranów. Mająca swoją premierę w roku 1970 Hydrozagadka Andrzeja Kondratiuka prezentuje o wiele bardziej subwersywny od Żbika przykład superherosa, który dokonuje radykalnego przeformułowania reguł wyjściowego monomitu. Występujący w produkcji kinowej As to z jednej strony znakomita parodia zachodnich Supermenów, z drugiej jednak, to mocno "tutejszy" kulturowo konstrukt, na wzór którego odpowiednio wystylizowana zostaje także PRL-owska rzeczywistość. Jak trafnie opisuje Asa Przemysław Dudziński: „Kawaler, nie pije, nie pali, szkołę ukończył z oceną celującą, sportowiec amator, finalista biegów przełajowych, przechodził szczepienia ochronne, w dzieciństwie nie chorował na świnkę, koleżeński, stały w uczuciach, punktualny obowiązkowy, nienaganny pracownik uśmiechnięty na co dzień, wszechstronnie aktywny, sprawny fizycznie i umysłowo. [...]. Tak więc źródłem nadnaturalnych mocy Asa nie jest pozaziemskie pochodzenie ani mniej lub bardziej udane eksperymenty naukowe, jak w przypadku wielu komiksowych herosów. To nagromadzenie w jednym ciele tylu cech wzorowego socjalistycznego obywatela tworzy... nadobywatela. Można spekulować, że nadczłowieczeństwo Asa potencjalnie dostępne jest dla wszystkich, jest on bowiem końcowym produktem systemu kształtowania idealnego człowieka socjalizmu, ostatnim etapem marksistowskiej wizji historii człowieka"12. W podobny do samego Asa sposób zostaje również przestylizowany wizerunek obowiązkowej dla działania superbohatera metropolii. Zdaniem Justyny Czai: „Charakterystyczna przestrzeń zachodnich opowieści o obdarzonych nadprzyrodzonymi mocami herosach, którą stanowi zachodnia metropolia (w taki sposób kreowane jest Metropolis w opowieściach o Supermanie czy Gotham City w historiach o Batmanie), zastąpiona została swojską

11 Tamże, s. 128.

12 P. Dudziński Geneza Asa - superbohatera Polski Ludowej. „Hydrozagadka” Andrzeja Kondratiuka jako kontranaliza społeczeństwa PRL-u, w: Superbohater. Mitologia współczesności?, red. A. Kuchta, Kraków 2012, s. 87. 
Warszawą. Zamiast drapaczy chmur, ruchliwych wielkomiejskich ulic, obserwujemy na ekranie Okęcie, na którym doktor Plama oczekuje przylotu Maharadży, Wisłostradę, bloki z wielkiej płyty będące symbolem socrealistycznego budownictwa, neon hotelu Bristol, po którym wspina się As"13. Także modus operandi polskiego czempiona zostaje znacząco zredukowany do, pod wieloma względami, przaśnej mikroskali stojącego przed nim zadania, gdyż „W amerykańskich komiksach i filmach nieustraszeni herosi, dysponujący nadludzkimi mocami, interweniują, by zapobiec globalnej katastrofie, ocalić przed zagładą mieszkańców metropolii, a nawet całą ludzkość, udaremnić próbę przejęcia władzy nad światem. Rodzimy superbohater wkracza do akcji, aby z warszawskich kranów znów popłynęła woda"14.

Jeśli Kapitana Żbika uznać za, do pewnego stopnia, kalkę narracyjnego schematu przypisanego komiksowym superbohaterom - zmodyfikowaną jedynie na poziomie ideologicznym - to filmowy As stanowić powinien tu archetyp pierwszego, parodystycznego polskiego superbohatera, który niewiele później po filmie Kondratiuka pojawił się także na kartach rodzimych komiksów. W przeciwieństwie do pomnikowego funkcjonariusza MO, As zdradza bowiem o wiele więcej „lokalnych” cech, zmuszając tym samym prowadzoną na jego potrzeby narrację do wejścia w fazę postheroiczną, tzn. rewizjonistyczną w kontekście klasycznego wzorca. „Nieudolne typograficznie logo Asa wydaje się ledwo trzymać na jego piersi, peleryna jest krótka, sięgająca mu tylko do pasa, plącze się raczej groteskowo, zamiast majestatycznie powiewać jako surogat flagi. Również supermoce Asa nie przedstawiają się koniec końców zbyt oszałamiająco, zwłaszcza pokazane za pomocą sprytnych, ale zupełnie oczywistych sztuczek realizatorskich sekwencje lotów. Reżyser niedostatki techniczne włączył tu po prostu w burleskowy dyskurs filmu i podkreślił tym samym groteskowe cechy superobywatela"15 - podsumowuje Przemysław Dudziński. Rzeczywiście warto tu podkreślić, że z racji zarysowanych wcześniej decyzji politycznych - wpływających na niemal całkowite ograniczenie dostępu czytelników do amerykańskich rysunkowych monomitów - rodzimy twórcy zainteresowani tą tematyką niemal natychmiast przejść musieli w swoim obrazowaniu superherosów do etapu ich parodyzacji oraz wspomnianej wcześniej rewizji, rozpoczynając tym samym właściwą

13 J. Czaja Superbohater made in Poland - parodia w "Hydrozagadce" Andrzeja Kondratiuka, "Images" 2014 vol. XIV/nr 23, s. 60.

14 Tamże. 
polską ewolucję komiksu superbohaterskiego od trzeciej z faz wyróżnionych przez Gertlera. Od początku lat 70. aż do początku XXI wieku polscy herosi ulokowani zostali zatem w wariancie opowieści subwersywnych ${ }^{16}$ (jak stwierdzić można za Marciem DiPaolo), czyli w schemacie bohaterów ironicznych, bardziej refleksyjnych i świadomych rządzących ich światem konwencji, stanowili jednak przede wszystkim odniesienie do zachodnich postaci, wobec zasadniczego braku „swojskich" superidoli.

Właściwym protoplastą tego rodzaju postherosów w polskim komiksie stał się oczywiście Orient Men Tadeusza Baranowskiego - postać, która zadebiutowała latem 1976 roku w pierwszym numerze pisma komiksowego „Relax”. Ten śmiesznie wyglądający, niski bohater(?) z dziwacznym kapeluszem-maską na twarzy i obowiązkową, powiewającą na wietrze peleryną niemalże od razu stał się doskonałym przykładem polskiego rewizjonizmu „superbohaterskiego", jako że oferował wiele ciekawych, intertekstualnych nawiązań do swych poważniejszych odpowiedników zza oceanu. Już swoiste wprowadzenie do pierwszej przygody Orient Mena sytuuje go mocno w wariancie postgatunkowym, o mocno pastiszowym charakterze: „Menów dzielimy, podobnie jak kawę, na: Super Menów, Wyborowych Menów i Orient Menów. A oto on, Orient Men - prywatnie. Spaceruje, rozmyśla... A oto on na służbie. Oddany sprawie, bez namysłu rusza z pomocą... pracując z poświęceniem... często zaniedbuje własne zdrowie. Ma dobre serce... w gniewie bywa straszny... ale potem jest mu przykro..."17. W przypadku powyższego opisu znaczące jest zastosowanie wobec niego swego rodzaju komentarza w postaci ilustracji, które patetyczny ton tekstu demontują kuriozalnymi wizerunkami herosa wpadającego w trakcie lotu wprost na ścianę lub też domagającego się księgi życzeń i zażaleń w lokalnym sklepie spożywczym.

Kolejne przygody Orient Mena zmierzają konsekwentnie coraz bardziej w kierunku metakomentarza obejmującego już nie tylko konkretne konwencje gatunkowe, ale i ich umocowanie ekonomiczne. Na pewnym etapie opowieści Baranowskiego pojawia się zatem bardzo bezpośrednie nawiązanie do amerykańskich komiksów superbohaterskich, realizowanych w ramach tzw. Ery Brązowej - często brutalnych, ale i kreujących herosów wyraźnie

16 Nawiązując tym samym raczej do tradycji amerykańskiego komiksu undergroundowego z lat 6o. XX wieku, czyli np. do serii Wonder Wart-Hog Gilberta Sheltona - tytułu będącego prześmiewczą reinterpretacją postaci Supermana i wszystkich przynależnych jej tropów fabularnych, gdzie przystojnego Człowieka ze Stali zastąpił "bohater” o wyglądzie prosiaka. 
zmęczonych swą szlachetną misją. Tak właśnie rozpoczyna się jeden z epizodów Orient Mena: „Minęło już blisko dwadzieścia lat od czasu ostatniego pojawienia się Orient Mena w życiu publicznym. Najstarsi ludzie opowiadali: Zapił się na śmierć piwem bezalkoholowym. Inni, że nie wytrzymał fali naporu zachodnich Supermenów i powiesił się na wieszaku w oczekiwaniu na lepsze czasy... Jeszcze inni, że zaszył się w odległym miejscu i medytuje"18. W zaledwie trzech kadrach ilustrujących powyższe fragmenty Baranowski trafnie podsumowuje i równocześnie ironizuje modne w ramach Ery Brązowej rewizje superbohaterskiej mentalności, utrzymane w duchu bardziej depresyjnych rysów charakterologicznych, takich jak chociażby wspomniana już słynna dekonstrukcja psychopatycznej postaci Batmana w Powrocie Mrocznego Rycerza Franka Millera. Polski autor okrasza jednak tę swoistą wiwisekcję kolejnym trafnym, metatekstowym komentarzem, po raz kolejny adresowanym do amerykańskich Supermenów, w przypadku których owa brutalizacja ich kolorowych przygód podszyta była oczywistym motywem finansowym, mającym na celu przywrócenie zainteresowania daną postacią poprzez jej reinterpretację. „Orient Menie, skąd ta niespodziewana decyzja o powrocie?"19 - zagaduje bohatera dziennikarz. „Mój autor otrzymał znakomite propozycje finansowe za zgodę rysowania mojej postaci. Może praktycznie żądać od wydawcy każdej sumy od zera w dół..."20 - odpowiada heros.

Orient Men stał się zatem wzorcem dla szerokiego kręgu kolejnych polskich postherosów, którzy zdominowali rodzimy rynek komiksowy aż do początku lat 200o. Wśród kontynuatorów filozofii Baranowskiego znaleźli się zatem Wilq Bartosza i Tomasza Minkiewiczów, Likwidator Ryszarda Dąbrowskiego, Ratboy Krzysztofa Owedyka i Ratman Tomasza Niewiadomskiego, a także Człowiek-Paroovka Marka Lachowicza czy Pogromca Pornografów Jerzego Szyłaka. Właściwie każda z powyższych postaci czy serii zasługiwałaby tu na osobne omówienie z racji indywidualnych zabiegów, jakie stosowali w ich przypadku konkretni twórcy celem zaproponowania własnego wariantu post-superheroizmu. Wśród najbardziej dominujących w powyższych tekstach praktyk znalazłaby się jednak z pewnością przerysowana hiper- przemoc, najlepiej widoczna w komiksie Dąbrowskiego. Likwidator to seria poświęcona tajemniczej postaci w charakterystycznej, czarnej kominiarce,

Tamże, s. 39.

19 Tamże. 
którą najtrafniej określić można jako skrajną radykalizację działania takich zachodnich herosów jak Punisher czy Batman, tzn. biorących prawo we własne ręce - a nierzadko i posuwających się do morderstwa - mścicieli. Jak twierdzi zresztą sam autor polskiego komiksu: „Likwidator jest komiksowym wyobrażeniem fanatycznego ekologa, który widząc niewielką z reguły skuteczność pokojowych form ochrony przyrody, wybiera przemoc i terror. Przy tworzeniu tej postaci inspirowałem się działaniami członków radykalnych grup ekologicznych w Anglii z lat 8o. (np. Animal Liberation Front), którzy napadali na myśliwych w lasach lub uwalniali zwierzęta z laboratoriów; no i oczywiście postacią i działalnością Teda Kaczyńskiego (Unabombera). Likwidator jest ekologicznym fundamentalistą, który nie ma złudzeń, że można pogodzić interesy cywilizacji i ludzkości z interesami dzikiej przyrody. [...]. Likwidator jest jednocześnie bandytą, filozofem i etykiem, estetą i brutalem, równym gościem i sadystą. [...]. Jego uwielbienie dla Natury ma wyraźnie zabarwienie religijne, estetyczne i metafizyczne. Likwidator wręcz deklaruje się jako wyznawca ateistycznej religii Matki Natury. Wyśmiewa prawicowość, lewicowość i tępi nihilizm"21. Rzeczywiście ekstremalność działań Likwidatora - wymierzona jednakowo w kler, polityków, neonazistów, skinów i zwykłych turystów zanieczyszczających drogę na Giewont - łączy się u Dąbrowskiego zarówno z mocnym podtekstem ideologicznym (przemawiającym do wyobraźni szczególnie dziś, w związku z działaniami aktualnej władzy wobec Puszczy Białowieskiej), jak i artystycznym. Dąbrowski, jak sam sugeruje, tworzy bowiem ekstremum komiksowej postaci nadczłowieka przede wszystkim pod względem moralnym - testując wytrzymałość konwencji rysunkowej przemocy, a nawet sugerując, że „też uważam, że czasami trochę przesadza. Zdaję sobie sprawę, że dla $99 \%$ populacji taki bohater jest nie do przełknięcia, po prostu nie mieści się w głowie. I o to chodzi"22.

Drugim ze szczególnie często pojawiających się zabiegów w ramach polskich postheroicznych monomitów jest oczywiście daleko idąca strategia prześmiewania „kanonicznych” elementów amerykańskich narracji. Z sytuacją taką czytelnik ma do czynienia chociażby w nonsensownym Człowieku Paroovce Lachowicza, który to heros „Zbudowany z nietrwałej wędliny przewiązanej recepturkami [...] jest osobnikiem niezłomnie stojącym po stronie dobra i zajadle zwalczającym zło. [...]. Jest natomiast niesłychanie pomysłowy,

21 Zob. http://dzikiezycie.pl/archiwum/2007/pazdziernik-2007/likwidator-komiksowa-groteskanad-rospuda-rozmowa-z-ryszardem-dabrowskim (27.06.2017). 
co bardzo mu pomaga odnosić sukcesy w zwalczaniu przestępców równie groteskowych, jak on sam: Człowieka Loda, Człowieka Grzyba, Człowieka Popkornu, Starego Pieca Kaflowego lub Pieroga Potwora"23. Specyfika komiksu Lachowicza nie kryje się jednak jedynie w rażącym przestylizowaniu charakterystycznych kryptonimów rysunkowych bohaterów i superprzestępców, ale ponownie w umiejętnym wpisaniu tych niewiarygodnych sylwetek w dobrze znajome konteksty kulturowe i społeczne. Jak podsumowuje Adam Rusek: „wiele z tych prezentujących abstrakcyjny humor opowiastek ukazuje przy okazji wstydliwą egzotykę krajowej rzeczywistości: plagę zaśmiecających środowisko plastikowych torebek, sale kinowe cuchnące popkornem, brudne toalety publiczne, wielką popularność tanich win owocowych itp."24.

Swego rodzaju intertekstualnym żartem wymierzonym w amerykańskich superbohaterów jest również Wilq braci Minkiewiczów - jeden z najważniejszych i najpopularniejszych polskich komiksów ostatnich lat, który w całości pomyślany został jako ciąg rewizji zachodniego modelu heroizmu. Już okładka pierwszego odcinka Wilqa zapowiada odwołanie się do tradycji gatunku, będąc przerysowaną (graficznie i koncepcyjnie) wersją słynnej okładki „Action Comics" nr 1, czyli pierwszej ilustracji prezentującej Supermana. Wilq nie unosi jednak w powietrzu amerykańskiej limuzyny, lecz swojsko wyglądające auto pokroju Cinquecento, które znacznie łatwiej zlokalizować można na polskich ulicach. Również następujące dalej intro - kontynuujące tradycję Orient Mena - także zdradza oznaki ironii zastosowanej przez twórców do zaprezentowania nowego herosa. „Oto Wilq - Superbohater. Wilq jest prawdziwym superbohaterem, nie takim złamasem jak ta ciota Spawn" - czytamy we wstępie. Te dwa krótkie zdania zdradzają główną mechanikę działania serii Minkiewiczów - celem jej pełnego zrozumienia i wychwycenia zawartej tu postgatunkowej parodii niezbędne jest osiągnięcie pewnych kompetencji w zakresie tradycji komiksowych superbohaterów. Czytelnik musi zatem rozpoznać przywołaną postać Spawna - mrocznego i brutalnego superbohatera z wydawnictwa Image Comics, musi także wychwycić dowcip w postaci personaliów pracującego w Opolu (rodzinnym mieście Wilqa) komisarza Gondora (akronim nazwiska komisarza Gordona z komiksów o Batmanie), a także skojarzyć przyzywający Wilqa symbol żółwia wyświetlany na opolskim niebie z Bat-sygnałem z komiksów wydawnictwa DC. Ponownie jednak, ów polski postmonomit zbudowany jest nie tylko na intertekstualnej grze 
z konwencjami, ale przede wszystkim na zrekonstruowaniu przaśności oraz mikroskali otaczającej Wilqa rzeczywistości: „Wilq w nocy jest superbohaterem, ale w dzień w agencji reklamowej Oko kopiuje teksty z Worda do Corela"25. Praca w korporacji czy liczne „uroki” życia wśród polskich blokowisk i dziejących się na ich terenach przestępstw to kolejne atrybuty fabuł poświęconych Wilqowi, które nadają mu jednak - jak zauważa Daniel Handzelewicz $^{\mathbf{2 6}}$ - charakteru antyheroicznego, podobnie jak w przypadku filmowego Asa, konfrontując mizerne atrybuty bohatera z jeszcze mniej widowiskowymi zagrożeniami dla opolskiej metropolii.

\section{Harda wersja superheroizmu}

Najdłuższą czasowo strategię polskich twórców komiksów, dotyczącą szukania swego rodzaju odpowiedzi na amerykańskie narracje superbohaterskie, należałoby zatem określić jako szukanie lokalnego wariantu postheroizmu, który cechują liczne zabiegi parodystyczne, rewizjonistyczne i subwersywne, mocno naginające amerykański monomit na potrzeby polskich realiów i możliwości „super” bohaterów. Należy tu jednak podkreślić, że nie jest to jedyny z dostępnych obecnie wariantów tego rodzaju opowieści, jako że lokalny rynek komiksowy doczekał się najwyraźniej narodzin bardziej klasycznych form historyjek o nadludziach w kolorowych kostiumach, mieszczących się w ramach "tradycyjnej” pierwszej i drugiej Fazy Gertlera oraz narracji , afirmatywnych" DiPaolo. Z tego rodzaju sytuacją mamy jednak do czynienia od stosunkowo niedawna - raptem od początku XXI wieku - jako że lata następujące po transformacji ustrojowej 1989 roku przyniosły błyskawiczne zachłyśnięcie się polskich czytelników pierwszymi, dostępnymi w oficjalnym obiegu za pośrednictwem wydawnictwa TM-Semic, przedrukami przygód amerykańskich „trykociarzy”. Jak pisze Łukasz Kowalczuk, szeroka oferta przedruków komiksów DC i Marvela - będąca swoistym „nalotem dywanowym"27 - która pojawiła się na polskim rynku dzięki polskiej filii koncernu wydawniczego Semic przyniosła natychmiastowe, lecz jednocześnie krótkotrwałe „nadrobienie” przez polskich czytelników wieloletniego braku właściwych przygód Supermana czy Spider-Mana. Ich zniknięcie nie wynikało

25 Wilq-Superbohater, scen i rys. B. Minkiewicz, T. Minkiewicz, BM Vision, Warszawa 2003, s. 9.

26 Patrz: D. Handzelewicz Wilq - realny antybohater " Zeszyty Komiksowe” 2004 nr 1.

27 Patrz: Ł. Kowalczuk TM-Semic. Największe komiksowe wydawnictwo lat dziewięćdziesiątych w Polsce, Centrala, Poznań 2013.

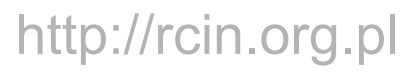


zresztą z szybkiego zmęczenia tą formą komiksu, lecz - jak sugeruje Przemysław Mazur - oznaczało raczej „niemożność finansowego podźwignięcia przez statystycznego czytelnika coraz to nowych serii wprowadzanych na nasz rynek"28. Stosunkowo nagły zmierzch popularności tytułów TM-Semic, przypadający już na koniec lat 9o., okazał się znaczący dla późniejszych możliwości pojawienia się „tradycyjnych” polskich superherosów, którzy mogli wreszcie uformować się nie w kontrze, ale na bazie swych amerykańskich odpowiedników - również niejako w odpowiedzi na sentyment, jakim spora część dzisiejszych odbiorców darzy niezbyt przecież odległą epokę TM-Semic.

Tym samym polski czytelnik doczekał się w końcu rodzimych wersji „afirmatywnych" narracji superbohaterskich, które dokonywały przechwycenia określonych wątków amerykańskiego monomitu, lecz nie w celu ich wyszydzenia, ale zaadaptowania. Z takimi właśnie seriami mamy do czynienia w przypadku Białego Orła braci Macieja i Adama Kmiołków, Blera Rafała Szłapy, „Polskiego Ducha” Piotra Gaszczyńskiego i Tomasza Kleszcza, Lisa Dariusza Stańczyka i Jakuba Oleksowa czy Incognito Piotra Czarneckiego i Łukasza Ciżmowskiego. Podobnie jak w przypadku postherosów pokroju Wilqa i Likwidatora, także i w kontekście bardziej „tradycyjnych” lokalnych bohaterów da się wyróżnić kilka cech dla nich wspólnych, wyznaczających jednocześnie najważniejsze punkty zbieżne między nimi samymi, a ich amerykańskimi odpowiednikami. Z całą pewnością zachowany tu zostaje zatem cały superbohaterski sztafaż, uwzględniający zarówno wygląd postaci, jak i ich nadludzkie zdolności oraz warunki działania. Kostium Białego Orła wizualnie przypomina zatem skrzyżowanie uniformów Kapitana Ameryki i Batmana, zaś Bler - niczym Quicksilver, czyli superszybki mutant z uniwersum Marvela - potrafi przemieszczać się z nadludzką prędkością. Polscy twórcy nie koncentrują się jednak wyłącznie na zaproponowaniu własnych wersji ikonicznej symboliki superbohaterów, lecz mniej lub bardziej umiejętnie włączają oni w swoje fabuły liczne nawiązania do schematycznych już wzorów narracji amerykańskich, pozwalając polskim postaciom nawet na częściową znajomość rządzących nimi konwencji. Niemal każdy z tego rodzaju tworów - np. Polski Duch i Lis - zyskuje w związku z tym swoje niezwykłe moce w wyniku działań polskiego(!) rządu lub tajemniczych korporacji, niczym dziesiątki ich odpowiedników zza oceanu. Towarzyszem Białego Orła - a zarazem mistrzem w poruszaniu się po internetowych bankach informacji - jest niejaki Hudini, bezpośredni odpowiednik postaci o podobnej funkcji zwanej Oracle 
ze świata Batmana. Sam Biały Orzeł zostaje zresztą obdarzony niezwykle charakterystyczną opowieścią o jego genezie, związaną z pojawieniem się gigantycznego orła (ponownie analogicznie do postaci Batmana, dla którego inspiracją staje się oczywiście nietoperz). Podstawą swego rodzaju superbohaterskiej reedukacji dla herosa z komiksu Szłapy stają się z kolei podsuwane mu do lektury polskie wydania amerykańskich komiksów, odwzorowujące faktyczne okładki pierwszych tytułów TM-Semic. Podobnie tajemniczy "Incognito" - sam mówiący o sobie, że stanowi dalekie echo postaci z filmu „Niewidzialny Człowiek” Jamesa Whale'a z 1933 roku - stwierdza w jednym z zeszytów: „W końcu doszedłem do wniosku, że jestem mutantem. [...]. No wiesz, jak X-Men"29.

Podstawową kwestią problematyczną w przypadku zarysowanych powyżej fabuł jest jednak to, że nawet proponując swego rodzaju większe uwrażliwienie modelu amerykańskiego superbohatera na lokalne kwestie i potrzeby, wciąż pozostają one mocno zależne od warunków funkcjonowania amerykańskiego monomitu. Należy bowiem uznać, że przygody Białego Orła i jego towarzyszy rzeczywiście są bardziej „świadome” polskiego kontekstu kulturowego - jego mitów, lęków i przesądów - zaś poszczególni twórcy niezwykle umiejętnie grają wykorzystywanymi stereotypami. Chociażby już w pierwszym zeszycie swoich przygód heros braci Kmiołek musi zmierzyć się z na wpół wampiryczną istotą, tzw. Nurem, zamieszkującą podziemia Dworca Centralnego w Warszawie i kontrolującą umysły stołecznych bezdomnych. Punktem wyjścia dla intrygi „Polskiego Ducha” okazuje się natomiast odkrycie przez głównego bohatera historii nieprawidłowości przy sprzedaży wybranych gruntów w Warszawie, co ściąga na niego uwagę tajemniczej organizacji przestępczej. Z kolei Bler przeprowadza jedną ze swych pierwszych superbohaterskich interwencji, aby uratować „Dziecko [które - przyp. T.Ż.] od miesięcy było bite i maltretowane. Wszystko wskazuje na to, że sprawcą był ojczym chłopca, obecnie znajdujący się na oddziale intensywnej terapii szpitala im. Jana Pawła II w Krakowie" ${ }^{\text {"30 }}$. Wszystkie te zabiegi „lokalizacji” zasadniczo nie ingerują jednak w bazową strukturę opowieści, odtwarzając dobrze już znane schematy w nieco zmienionej jedynie scenerii.

Hegemonia amerykańskiego monomitu objawia się tu zresztą nie tylko poprzez podążanie za narracyjnymi i ideologicznymi wymogami

29 Incognito. Skóra i krew - część 2, scen. P. Czarnecki, rys. Ł. Ciżmowski, Sol Invictus, Warszawa 2017, S. 20. 
superbohaterskiej opowieści (bohater ratuje społeczność, bohater powraca do swej samotni ponad społecznością itd.), ale także poprzez próbę zrekonstruowania strukturalno-ekonomicznych warunków funkcjonowania dla tego typu rozrywki. Mam tu na myśli przede wszystkim podejmowaną już od jakiegoś czasu w polskim komiksie popularnym próbę wykreowania swego rodzaju rodzimego superbohaterskiego uniwersum - na wzór uniwersów DC i Marvela - tzn. zestawu tekstów komiksowych tworzących spójną i współzależną od siebie sieć fabuł poświęconych poszczególnym herosom. Najsilniej tego rodzaju potrzebę zdradzają chociażby twórcy Białego Orła, Lisa czy Blera, które to postacie zdają się coraz jawniej egzystować w paraamerykańskim systemie wizualno-fabularnym. Oczywiste nawiązania do stylu rysunku amerykańskich rysowników (jak chociażby w przypadku rozerotyzowanego wizerunku Syreny z uniwersum Białego Orła), ale też i rozrastające się w kontekście danej serii liczne paratekstualne luki i sugerowane powiązania czekają już tylko na zwiększenie produkcyjnych i konsumpcyjnych możliwości swoich twórców oraz odbiorców. Ci ostatni zresztą wykazują wyraźną tendencję wzrostową w zakresie swoich potrzeb, co obrazuje niezwykle duże zainteresowanie czytelników zakupem ekskluzywnych wariantów okładkowych Biatego Orła (co stanowi praktykę zaadaptowaną wprost z rynku amerykańskiego) czy też powstałą na bazie uniwersum Lisa grą karcianą, tym dobitniej udowadniając jednak nie wprost wyrażoną nadrzędność amerykańskiego modelu komiksu popularnego.

Polski schemat komiksowych narracji superbohaterskich nie ogranicza się jednak jedynie do wariantów subwersywnych/antyestablishmentowych i afirmatywnych, choć zdecydowanie te właśnie kategorie przeważają na lokalnym rynku. Wśród oferty wydawców natrafić jednak można na rodzimy tytuł w mojej opinii bezprecedensowy w skali komiksu polskiego. Mowa tu o projekcie Jakuba Kijuca Jan Hardy - Żotnierz Wyklęty, który proponuje niezwykle ciekawe sposoby lektury, sytuując się jednocześnie na przecięciu subwersywnych i afirmatywnych strategii. Uważam bowiem, że Jan Hardy to tekst w autorski sposób łączący w sobie metatekstualne spojrzenie zarówno na postironiczne postacie pokroju Wilqa, jak i klasycznych herosów w rodzaju Białego Orła, tworząc jednocześnie trzeci, hybrydowy wariant polskiego monomitu.

Już wyjściowy zamysł autora, sytuujący tytułowego herosa w kontekście niezwykle nośnej współcześnie społeczno-politycznej narracji na temat Żołnierzy Wyklętych, zapowiada ciekawą grę z tradycją superbohaterską. „W 1945 roku dla świata wojna dobiega końca... Tymczasem Polacy muszą walczyć 
dalej. Trwa powstanie antykomunistyczne. Powstanie, w którym biorą udział ludzie o nadzwyczajnych mocach i umiejętnościach, zwani Hardymi... Dlaczego o nich nie pamiętasz?"31 - tak swoją historię rozpoczyna Kijuc. Pomijając oczywiste, jak już wspomniałem, aluzje historyczne, Jan Hardy szybko okazuje się jawną kpiną z tradycyjnych narracji superbohaterskich - kpiną nie osiąganą jednak poprzez zabiegi parodiujące figurę herosa, ale raczej poprzez jej hiperideologizację. Już pierwsza manifestacja nadludzkiej siły Hardego obdarzona jest znamiennym komentarzem autora: „Panowie, cokolwiek by się działo... pamiętajcie trzy słowa. Słowa, które dają moc! Bóg! Honor! Ojczyzna!"32. W dalszej części pierwszego zeszytu czytelnik poznaje zresztą bardziej „pogłębione” uzasadnienie niezwykłego pochodzenia supermocy bohatera: „Każdy stolem czerpie siłę ze swej niezłomności i siły charakteru. Ja jestem katolikiem i patriotą. Moja siła to wartości, które powinny być bliskie każdemu Polakowi. A są to: Bóg, Honor i umiłowanie Ojczyzny"33. „Niesamowite!” - słyszy Hardy w odpowiedzi - „Określamy takich ludzi mianem Hardych. To znaczy część dowództwa optuje za określeniem superbohater. Moim zdaniem [...] Hardy brzmi lepiej"34. Konserwatyzm światopoglądowy jest wielokrotnie przytaczany w komiksie w kontekście relacji między źródłem niezwykłej mocy Hardych (oddziału podziemnych superżołnierzy), a ich największą słabością, czyli liberalizacją idei. Już w trzecim zeszycie serii pada znamienna konstatacja ze strony jednego ze złoczyńców: „Widzi Pan tę kostkę cukru? Jest jasno określona w kształcie i zbita. Jest twarda i solidna. [...]. A teraz... zamieszam. [...]. Do naszego cukrowego bohatera przyszła śmierć. Śmierć przez rozpuszczenie. Rozmycie wartości, idei... Tak zwanej prawdy"35.

Także rysunkowa warstwa komiksu Kijuca stanowi interesującą, ponownie hybrydową, formę, teoretycznie zachowując wymogi amerykańskiej superheroicznej stylistyki przy jej jednoczesnym jednak „zlokalizowaniu". Jeśli bowiem, jak trafnie zauważają Randy Duncan i Matthew J. Smith, wizualną stylizacją superherosów rządzą dwie reguły: masywność

31 Jan Hardy. Żołnierz Wyklęty. Tom 1, scen. i rys. J. Kijuc, Materia Komiks, Warszawa 2014, s. 1.

32 Tamże, s.5-6.

35 Jan Hardy. Żołnierz Wyklęty. Tom 3, scen. i rys. J. Kijuc, Materia Komiks, Warszawa 2014, s. 36-38.

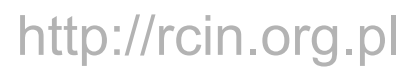


sylwetek i ich erotyzacja ${ }^{36}$, to Hardy i jego komiksowi kompani pozostają zasadniczo wierni powyższym konwencjom, zaproponowanym tu jednak w bardziej „prawomyślnym” wydaniu. Tytułowy heros jest zatem oczywiście postacią muskularną, o szerokich barkach, wyrzeźbionych mięśniach i jednocześnie dość wątłej, w porównaniu do reszty ciała, talii (przywołując tu zresztą liczne konotacje z postbohaterskimi, ironicznymi reinterpretacjami superbohaterskiego wyglądu, jako kontrastu między przerośniętą górną a cherlawą dolną partią ciała). Całkowicie wbrew oryginalnej tradycji wizualnej prezentuje się jednak uniform Hardego, będący znaczącym zaprzeczeniem idei kostiumu superbohatera jako elementu erotycznego. Kostium podkreślający, w klasycznych wariantach amerykańskiego monomitu, zmysłowość męskich i żeńskich sylwetek oraz podświadomą fascynację wybranymi fragmentami anatomicznymi, jak kobiecie piersi czy męskie krocze (odpowiednio zresztą sygnalizowanymi przez częściowo odsłonięte biusty czy też słynne przykłady bielizny noszonej na wierzchniej warstwie kostiumu) w przypadku Jana Hardego traci swój seksualny potencjał. Polski heros odziany jest w aseksualny uniform, w całości przesłaniający jego ciało i przede wszystkim nie przyciągający w jakimkolwiek stopniu uwagi czytelnika celem kontemplowania jakiegokolwiek elementu ciała Hardego. Dodatkowym, ,aseksualizującym” zabiegiem jest tu także sama kreska Kijuca - nieco bardziej ekspresyjna niż w przypadku typowego komiksu superbohaterskiego - która sprawia, że cielesny wizerunek polskiego superbohatera staje się nie cielesnością fantazmatyczną (fetyszyzowaną) a bardziej fantomową (umowną). W rezultacie, jedyną pozostałością po widowiskowych zbrojach amerykańskich "hardych" nadludzi pozostaje tutaj jedynie szybko rozpoznawalny symbol - wielkie $\mathrm{H}$, dumnie noszone przez Jana Hardego na piersi.

$\mathrm{Na}$ tle powyższych uwag widać wyraźnie, jak wielkim wyzwaniem szczególnie dla polskiego czytelnika - jest okiełznanie superherozimu Jana Hardego. Pomijając już konieczność ustosunkowania się do zawartej w tytule mitologii Żołnierzy (w tym wypadku superbohaterów) Wyklętych, Jan Hardy przechwytuje amerykański monomit znacznie go „lokalizując” - zarówno w czasie, jak i kontekście kulturowo-ideologicznym. Czyniąc to, Kijuc nie odtwarza jednak mimowolnie wzorca zachodniego, Hardy nie jest typem społecznego mściciela - pokroju Supermana - nie sytuuje się ponad

36 R. Duncan, M.J. Smith The Power of Comics. History, Form \& Culture, Continuum, New YorkLondon 2009, s. 235-236. 
społecznością czy też nawet własną rodziną, ale, jak sam podkreśla, dąży do ponownego włączenia się w żywot dobrego męża i ojca, a zarazem Polaka i katolika. Wiele cech jego charakteru i zachowania - jak modlitwa za pokonanego wroga czy wspomniane przywiązanie do wartości rodzinnych stawiają wręcz bohatera w opozycji względem silnie indywidualistycznych amerykańskich bohaterów. Ostateczna ocena specyfiki komiksu Krijuca nie jest zatem łatwa i stanowi kolejny etap pracy, jaką z tekstem wykonać musi czytelnik. Z jednej strony bowiem, nie ulega wątpliwości, że na poziomie diegezy komiksu Jan Hardy mamy do czynienia z narracją jasno zdefiniowaną ideologicznie, wpisującą się w aktualnie popularny dyskurs popularyzujący i rehabilitujący tzw. Żołnierzy Wyklętych. Dodatkowo wydźwięk ten wzmacniają liczne - umieszczane w każdym zeszycie - reklamowe wkładki zapraszające do zakupu „patriotycznej” odzieży. Z drugiej jednak strony, autor bardzo często sytuuje się tak blisko prawicowej „hiperstylizacji”, że właściwie trudno uznać, że traktuje ją całkowicie serio. Chociażby w ramach swoistych paratekstów do głównej serii Jan Hardy, czyli zbioru dwóch tomików o tytule ROTA XXI, Kijuc proponuje absurdalne wręcz tropy fabularne w postaci, np. wprowadzenia figury Telimena - transwestyty, którego credo brzmi: „Płeć i wiek nie ma znaczenia. Chodź do Telimena” czy też tzw. Tęczozilli, potwora nawiązującego wprost do Tęczy na Placu Zbawiciela w Warszawie, który zostaje pokonany przez... spalenie.

Poprzez opisane powyżej hiperideologiczne i hiperstylistyczne zabiegi, Jan Hardy okazuje się lekturą, która proponuje rewizję zarówno klasycznego modelu opowieści superbohaterskiej, jak i jej postwariantu, czyli w domyśle narracji bardziej samoświadomej i kpiarskiej. Wyjątkowość komiksu Kijuca polega w moim przekonaniu na tym, że umiejętnie porusza się on między poetyką kpiarską i poważną, co znacznie poszerza spektrum możliwych odczytań Hardego w zgodzie z objętą optyką i kompetencją czytelnika. Jest to wreszcie komiks, który najwłaściwiej dokonuje sygnalizowanej już wielokrotnie "lokalizacji” amerykańskiego monomitu, proponując w zastępstwie monomit polski, zbudowany na bogatym zestawie rozpoznawalnych symboli i metafor narodowych - ocierających się wręcz o tropy nacjonalistyczne - a poprzez silne zaakcentowanie określonego dyskursu politycznego, tym bardziej zapraszający do dyskusji obie strony politycznej sceny. W kontekście historii komiksu polskiego Jakub Kijuc proponuje opowieść, która nie odrzucając całkowicie zachodniego modelu, potrafi twórczo wybrać z niego określone elementy, zapoczątkowując tym samym - miejmy nadzieję - dłuższą serię czy też nawet Hardo-centryczne uniwersum rysunkowe. 
Kompleksowe omówienie w ramach pojedynczego tekstu bogactwa tradycji polskich komiksów o superbohaterach jest oczywiście niemożliwe i nie było z pewnością intencją autora niniejszego opracowania. Sądzę jednak, że przedstawiona powyżej analiza posiadać może co najmniej dwa zasadnicze znaczenia dla - koniecznych moim zdaniem - dalszych badań nad rodzimą produkcją komiksową tego rodzaju. Po pierwsze, celem moim było wstępne określenie spektrum możliwości, jakie pojawiały się przed polskimi autorami w związku z zaadaptowaniem na polski grunt opowieści o nadludzkich herosach. Po drugie, chciałem wyraźnie zaakcentować także konieczność podjęcia wskazanych badań w perspektywie komparatystycznej, tzn. konfrontującej lokalnych twórców z przebogatą przecież historią zarówno amerykańskich, jak i światowych dokonań na wskazanym polu. Artykuł niniejszy w żadnej mierze nie może być zatem uznany za wyczerpujące opisanie mitu polskiego superbohatera. Może i powinien on jednak zapraszać do dyskusji na temat historii oraz współczesnej kondycji polskiego monomitu w obliczu rosnącej popularności tego rodzaju opowieści na zarówno komiksowym, jak i multimedialnym rynku.

\section{Abstract}

\section{Tomasz Żaglewski}

ADAM MICKIEWICZ UNIVERSITY (POZNAŃ)

The White Eagles of Comics: The Specific of Polish Superhero Narratives

Żaglewski outlines the most important examples of Polish comic texts with a focus on superheroes. Using an approach based on media comparative studies, he examines common and individual aspects of comic series from the US and Poland. The main goal is to define the Polish superhero monomyth as a local version of the American monomyth, which is strongly codified both in terms of theme and ideology, and which serves as a foundation for superhero stories. This allows Żaglewski to distinguish subversive and affirmative Polish variations of Western superheroic tales.

\section{Keywords}

American comic books, Polish comic books, superheroes, American monomyth

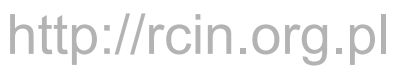

